\title{
Modified Konno instead of myectomy: Another tool in the box?
}

\author{
Joseph A. Dearani, MD
}

\author{
From the Department of Cardiovascular Surgery, Mayo Clinic, Rochester, Minn \\ Disclosures: Author has nothing to disclose with regard to commercial support. \\ Received for publication July 13, 2018; accepted for publication July 16, 2018; available ahead of print Aug 16, \\ 2018. \\ Address for reprints: Joseph A. Dearani, MD, Department of Cardiovascular Surgery, Mayo Clinic, 200 First St \\ SW, Rochester, MN 55905 (E-mail: jdearani@mayo.edu). \\ J Thorac Cardiovasc Surg 2018;156:2295-6 \\ $0022-5223 / \$ 36.00$ \\ Copyright (C) 2018 by The American Association for Thoracic Surgery \\ https://doi.org/10.1016/j.jtcvs.2018.07.039
}

The modified Konno procedure to treat obstructive hypertrophic cardiomyopathy (HCM) has not been widely applied because the early and late results of extended septal myectomy have been excellent. In general, extended septal myectomy has been the criterion standard for patients with symptoms of all ages, including children with HCM refractory to medical therapy. With that said, the surgical management of HCM in children continues to be a challenge, particularly for those with Noonan syndrome. Laredo and colleagues $^{1}$ are to be congratulated on their results, published in this issue of the Journal, of a series of 79 children who underwent a modified Konno procedure as a strategy to treat obstructive HCM.

Strengths of the report of Laredo and colleagues ${ }^{1}$ include reasonably large numbers of (1) young patients, younger than 5 years old $(38 \%)$; (2) patients with concomitant right ventricular outflow tract (RVOT) obstruction (28\%); and (3) patients with Noonan syndrome (25\%). In addition, approximately $5 \%$ of the patients were infants. Patients with these features are indeed the most challenging to deal with surgically. The most important finding in the review of Laredo and colleagues ${ }^{1}$ is the absence of recurrent left ventricular outflow tract obstruction at 6-year followup. In addition, Laredo and colleagues ${ }^{1}$ have extensive experience with the modified Konno procedure, particularly with their maneuvers to reduce heart block. The technical pearls included in their current review (and in their previous articles) are invaluable to any surgeon wanting to learn more about the modified Konno procedure.

The most important limitation of this review is the absence of a direct comparison between septal myectomy and the modified Konno procedure to allow a better understanding of superiority of one relative to the other. Other limitations include no clear definition of how Laredo and colleagues ${ }^{1}$ defined "high-risk" children. Does this refer to extent of septal thickness, presence of biventricular outflow tract obstruction, presence of Noonan syndrome, operation performed during infancy, or presence of diastolic dysfunction? Each of these factors contributes in some way

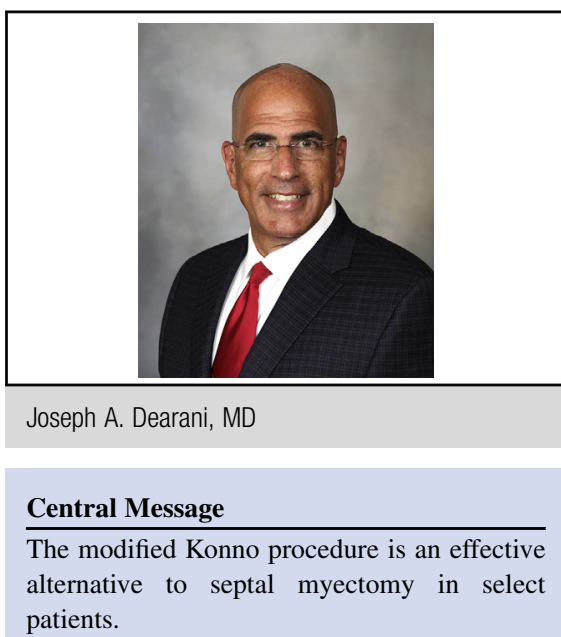

See Article page 2285. to elevated risk related to surgery. What is clear is that not all of their patients had these features and that the $6 \%$ early mortality and the $11 \%$ rate of heart block requiring permanent pacing are not low. Whether this result is due to patient substrate (features described previously) or is due to the procedure itself is not clear, but it is likely related to a combination of both. In addition, there is a lack of anatomic detail from echocardiography (eg, aortic annulus size, point of mitral-septal contact from the aortic annulus) to determine whether septal myectomy would have been a more appropriate procedure that could have been performed effectively with a lower risk of early death and heart block.

Strengths and weaknesses of this review aside, there are a number of pearls and pitfalls regarding surgery for obstructive HCM in children that are worth mentioning. First and most important, a proper extended left ventricular septal myectomy and a modified Konno procedure are both effective in abolishing the dynamic outflow tract gradient with obstructive HCM. Both procedures are associated with low early mortality, ${ }^{2,3}$ but both can result in aortic or mitral valve injury or in heart block. The most important technical pearl with regard to septal myectomy is apical extent of the myectomy trough so that it is opposite the anterior mitral leaflet, the chordae, and the papillary muscles. This can be difficult to accomplish when the aortic annulus is small, as is often the case in infants and 
very young children. A concomitant transapical myectomy is an important adjunct to a transaortic septal myectomy that facilitates midventricular obstruction when the reach from the aortic side is limited. ${ }^{4,5}$ Second and equally important, the results of either the myectomy procedure or the modified Konno procedure are operator dependent; that is, surgeons with substantial experience with one procedure (or the other) will be able to perform the operation safely and effectively (eliminate or significantly reduce the gradient).

Ideally, one would choose a particular procedure on the basis of anatomic findings from echocardiography. These data include the diameter of the aortic annulus, the point of mitral septal contact and its distance from the aortic annulus, the presence of midventricular obstruction, and the presence of structural abnormalities with the mitral valve. In addition, the presence of RVOT obstruction should also be determined, particular in the setting of Noonan syndrome. The most favorable features for transaortic extended septal myectomy include a reasonably sized aortic annulus with a point of obstruction that is high in the left ventricular outflow tract (the basal septum). The presence of midventricular obstruction may require a concomitant limited left ventricular apical incision that provides excellent exposure of the hypertrophied septum and complete abolition of the gradient. The least favorable feature for transaortic myectomy is a small aortic annulus that results in poor exposure of the ventricular septum, particularly if the obstruction extends further into the ventricle at the midventricular level. This group of patients is typically very young, usually in infancy, and may be best served with a modified Konno procedure as described by Laredo and colleagues. ${ }^{1}$

The principal treatment of RVOT obstruction revolves around a right ventriculotomy and placement of a patch in the RVOT. ${ }^{5}$ This approach is essential because the ability to do an extensive septal resection on the right side is limited by the numerous tricuspid chordal attachments and inadequate septal and right ventricular free wall exposure across the small tricuspid valve orifice in young children. The strategy of RVOT patch reconstruction to treat right-sided obstruction is completely independent of the surgical approach that is used on the left side (myectomy or modified Konno).

It should be emphasized that medical management ( $\beta$-blockers, calcium-channel blockers) is the mainstay of initial treatment of patients with symptoms and can be quite effective at reducing a dynamic outflow tract gradient on the left or right side. An aggressive and thoughtful medical regimen can often delay the need for surgery until the child is older (and larger), thus making any surgical option technically easier. Finally, whereas myectomy surgery in adults is often considered "curative" because of low recurrence rates of obstruction and a late survival that is equal to that of an age-matched population, the long-term outlook in children is considerably different, particularly when septal reduction therapy is required at a very young age. The presence of significant ventricular hypertrophy in children is almost always associated with some degree of diastolic dysfunction and restrictive physiology, rendering any surgical procedure more "palliative" in the pediatric age group.

At the end of the day, there are multiple effective ways to treat obstructive HCM. How one decides is determined by anatomic details and the individual surgeon's personal experience. The modified Konno is a good option in the right patient and provides another "tool in the box" for the surgeon's armamentarium when dealing with this technically challenging disease in young children.

\section{References}

1. Laredo M, Khraiche D, Raisky O, Gaudin R, Bajolle F, Maltret A, et al. Long-term results of the modified Konno procedure in high-risk children with obstructive hypertrophic cardiomyopathy. J Thorac Cardiovasc Surg. 2018;156:2285-94.e2.

2. Caldarone CA, Van Natta TL, Frazer JR, Behrendt DM. The modified Konno procedure for complex left ventricular outflow tract obstruction. Ann Thorac Surg. 2003; 75:147-51; discussion 151-2.

3. Altarabsheh SE, Dearani JA, Burkhart HM, Schaff HV, Deo SV, Eidem BW, et al. Outcome of septal myectomy for obstructive hypertrophic cardiomyopathy in children and young adults. Ann Thorac Surg. 2013;95:663-9; discussion 669.

4. Kunkala MR, Schaff HV, Nishimura RA, Abel MD, Sorajja P, Dearani JA, et al. Transapical approach to myectomy for midventricular obstruction in hypertrophic cardiomyopathy. Ann Thorac Surg. 2013;96:564-70.

5. Poterucha JT, Johnson JN, O’Leary PW, Connolly HM, Niaz T, Maleszewski JJ, et al. Surgical ventricular septal myectomy for patients with Noonan syndrome and symptomatic left ventricular outflow tract obstruction. Am J Cardiol. 2015; 115:1116-21. 